\title{
BUSINESS RISK, FINANCIAL RISK AND FIRM PERFORMANCE AN EMPIRICAL STUDY OF INDONESIAN MANUFACTURING SECTOR
}

\author{
Utami Prasetiawati ${ }^{\mathrm{a}}$ \\ I Made Sudana ${ }^{b}$ \\ ${ }^{a}$ Sekolah Pascasarjana Universitas Airlangga ${ }^{\mathrm{b}}$ Fakultas Ekonomi dan Bisnis Universitas Airlangga \\ Email: tinautami2015@gmail.com ${ }^{\mathrm{a}}$; imadesudana@yahoo.co.id ${ }^{\mathrm{b}}$
}

ARTICLE HISTORY

Received:

29 Januari 2019

Revised

25 Februari 2019

Accepted:

9 March 2019

Online available:

14 Mei 2019

Keywords:

Degree of operating leverage(DOL), Degree of financial leverage(DFL), size, Return on equity (ROE), and Market to book (MTB)

\begin{abstract}
Introduction: This paper empirically examines the impact of degree of operating leverage (DOL) and degree of financial leverage (DFL) to firm performance by using size as control variable. Firm performances used are return on equity (ROE) and market to book ratio (MTB).

Methods: Statistical tool used is pooled regression while sample used is all Indonesian manufacturing firms listed in Indonesia Stock Exchange from 2009-2013.

Results: The findings revealed that high fixed asset firms pose higher DOL compared to those of lower ones; and highly financial leveraged firms pose significantly higher DFL compared to those of lower financial leveraged ones. Further, both DOL and DFL impacting ROE in negative manner but only DOL is statistically significant, while all variables (DOL, DFL and Size) impacting MTB in negative manner but only size is statistically significant.

Conclusion and suggestion: The finding shows that Indonesian stock market investors do not regard risks as important elements in making investment decisions. The findings, however, pose a quite low $\mathrm{R}$ squared value of $1.39 \%$ for ROE and $2.4 \%$ for MTB. This means only those percentage of ROE and MTB can be explained from the variables used in this research. Thus, the author encourge more variables should be included in the future research, including macro economic variables, as it is one of the key component in firm performance.
\end{abstract}




\section{INTRODUCTION}

In globalized economy, business faces tremendous challenges and competitiveness. Business success hence is not merely centered on the profit, but also on proper risk management. In managing business, manager faces two major risks, that is, business risk and financial risk. Business risk involves investment decision a manager makes i.e decision to purchase fixed asset, while financial risk involves financing decision a manager chooses to take i.e: the decision to choose debt instead of equty in financing a certain investment/project.

Fixed asset is of particular important as it is often firms' single largest component of total asset. Wrong investment decision of fixed asset might lead firms into many unhealthy conditions including cash flow ability to service debt or liquidity problems. Manufacturing industries is interesting as they typically rely on assets to produce sales. By measuring ratio of fixed asset to total asset ratio, we can classify wether a firm is high or low fixed asset firms. Firms who have high ratio of fixed asset to total asset ratio then intuitively have high business risk. One common method to measure business risk is by using Degree of Operating Leverage (DOL). DOL measures the changes of EBIT over changes of sales. Thus, it measures how changes per unit of sales effect changes of EBIT. The higher the DOL, the higher is the business risk. The second risk, financial risk signals how manager choose to finance firm investment. Total liability over total asset ratio is an intuitive measurement of level of debt a firm is taking. High ratio of total liability over total asset should indicate that firm is highly financial leveraged, and vice versa. In finanace, common method to measure financial risk is by using Degree of Financial Leveragel (DFL). In this research, we provide empirical evidence on these theoretical models by examining if highly fixed asset firms pose higher DOL compared to lowly fixed asset firms; if highly financially leveraged firms pose higher DFL compared to those of lowly financial leveraged firms and finally, the impact of DOL, DFL and size (serving as control variable) to firm performances. Firm performances used are return on equity (ROE) for accounting performance and market to book ratio (MTB) for market performance.

\section{LITERATURE REVIEW}

\section{The traditional society}

\section{Business Risk and Financial Risk}

Business risk is the existance of risk arises due to invesment decision. Firms who, in their operational activites, employing high level of fixed asset (or high fixed asset to total asset ratio) are identified as high fixed asset firms. High fixed asset firms are perceived to be on higher business risk compared to low fixed asset firms due to the fact that during the economic downturn they are less flexible to adapt their cost structure. 
At the same token, during economic expansion, these firms are on better advantage as they incur less cost per unit production and therefore profitting more compared to lower fixed asset firms. The explanation for this is because high fixed asset firms have high fixed cost and consequently higher depreciation cost. This cost does not adapt easily when there is change in demand.

Low fixed asset firms, on the other hand, are low on fixed cost but high on variable cost. During economic downturn, they have option to cut down their variable cost, either by employing less workers or employing them at reduced working hour to save cost. During economic expansion, they can adapt themselves again according to demand. For these reasons, low fixed asset firms are perceived to be at lower business risk compared high fixed asset ones. Risk is often perceived as deviation of from the expectation. Business risk is commonly measured by degre of operating leverage (DOL). Operating leverage exists as consequence of changes in operational cost due to the use of asset. Thus, the higher the DOL, the higher is the business risk, and vice versa.

$D O L_{i t}=\frac{\% \Delta E B I T_{i t}}{\% \Delta \text { Sales }_{i t}}$

DOL: Degree of Operating Leverage of firm $i$ at time $t$

EBIT: Earning Before Interest and Tax of firm $i$ at time $t$

$\triangle E B I T_{i t}=\frac{E B I T_{i t}-E B I T_{i t-1}}{E B I T_{i t-1}}$

Sales: Total sales of firm $i$ at time $t$

$\Delta$ Sales $_{i t}=\frac{\text { Sales }_{i t}-\text { Sales }_{i t-1}}{\text { Sales }_{i t-1}}$

Financial risk is a risk that occurs due to the financing decision due to employing capital that creates fixed cost. Firms whose activity involve high degree of debt tend to have higher financial risk compared to those who have less debt. This is due to the fact that during economic downturn that results in lower sales, firms who are highly in debt is on higher risk of bankruptcy compared to those who have less debt as they still have to pay the same amount of interest regardless of lower earning due to the lower sales. At the same token, as debt also creates value and provide tax shield, during economic expansion, firms with higher debt are on the better advantage as they can maximize earning with the higher operational capacity they creates from debt. Thus, firms' level of financial risk is dependent on their level of financial leverage. The higher the firm' financial leverage, the higher is the financial risk, and vice versa. Commonly financial leverage used measure is degree of financial leverage (DFL) with the following formula:

$D F L_{i t}=\frac{\% \Delta E A T_{i t}}{\% \Delta E B I T_{i t}}$

$D F L_{i t}$ : Degree of Financial Leverage of firm $i$ at time $t$

$E A T_{i t}$ : Earning After Tax of firm $i$ at time $t$

Published by University of Airlangga.

This is an open access article under the CC BY license (https://creativecommons.org/licenses/by-sa/4.0/) 
$\Delta E A T_{i t}=\frac{E A T_{i t}-E A T_{i t-1}}{E A T_{i t-1}}$

$E B I T_{i t}$ : Earning Before Interest and Tax of firm $i$ at time $t$

\section{Firm Peformance}

Financial performance answers fulfilment of firm's economic goal. There are two kinds of firm performance measure currently used: accounting performance and market performance. Accounting performance is a firm performance that measured based on accounting information provided in the financial report. As maximizing shareholder value is one of firm's priority goal, therefore ROE is single most important firm's performance yardstick. ROE measures the efficiency of firm' managing shareholder's equity. The higher the ROE, the better the management manage its' shareholder's capital. ROE is calculated by:

$R O E_{i t}=\frac{E A T_{i t}}{\text { Equity }_{i t}}$

$R O E_{i t}:$ Return on Equity of firm $i$ at time $t$

$E A T_{i t}$ : Earning After Tax of firm $i$ at time $t$

Equity $_{i t}$ :Total Equity of firm $i$ at time $t$

The second performance measure is market based performance. Market performance is firm performance being measured based on investor' response toward firm's condition. How investor's response toward firm's condition is by large captured in firm's stock price. Therefore, firm with high MTB value reflects market have higher expectation toward firm' performance (overpriced), and vice versa. It is measured by the following formula:

MTB $=\frac{{\text { Market } \text { Value }_{i t+1}}_{\text {Book }_{\text {Value }} \text { it }}}{\text { MT }}$

$M T B_{i t}$ : Market to book ratio of firm $i$ at time $t$

Market Value $_{i t}$ : Stock price of firm $i$ at time $t+1$

Book Value $_{i t}: \frac{\text { Total Equity }}{\text { Number of common stock }}$

\section{Impact of DOL DFL to Firm Performance}

Return on Equity (ROE) measures nett income as percentage of stockholder's equity. High ROE firm means it generates more profit per dollar of equity, while operating leverage measures how much a firm's net income changes based on changes in sales. Thus, a higher DOL boosts ROE when sales rise, but it also accelerates the decrease in ROE when sales decline. Market to book ratio shows market expectation toward firm's potential earning. High DOL firms show firm's strong commitment toward market it enter and therefore potentially impact market expectation toward firms' future earning, and vice versa. During good economic condition, high commitment toward market brings good market expectation, however during economic recession, high 
commitment toward market signals negative market expectation as firm's future earning will decline.

Degree of financial leverage (DFL) measures the changes of EAT as consequence of changes of EBIT. As debt carries interest, higher debt brings positive impact toward ROE only when firm' return is greater than interest it pays. On the other hand, when firm' return is lower than its interest rate it has to pay as consequence of its leverage, it brings negative impact toward ROE. MTB, as it measures market' expectation toward firms' future earning, during good economic condition, higher leverage adds capacity to firm's current capacity and therefore potentially bring higher earning. Hence, will raise its MTB value. On the other hand, during economic downturn, higher financial leverage translate into higher obligation during lower sales and therefore decreases potential earning and subsequently, negatively correlated to MTB.

Evans (1987) stated that big firms undoubtedly have more access toward fundings compared to their smaller counterparts. These fundings can translate into lower cost of fund, better machinaries or higher quality of human resources which at the end boost up these big firm's performance. Regardless to the fact that big firm' absolute amount of asset is bigger compared to smaller firm, however, there is a maximum rate at which each individual firm can grow under given circumstances. Such growth are limited by various factors both internally and externally. Among others, internally, big firms tend to face bigger agency problem while externally, they are limited by saturated demand. Thus, at certain level, performance growth drops as the size reached to its optimum level.

\section{Impact of Size Toward Performance}

Firm size can be measured by amount of asset owned by certain firm. As asset is valid collateral means required by creditors, the bigger is the firm, the bigger is its access toward funding. More access toward funding translates into more funding options and finally cheaper cost of fund and subsequently higher nett income. As ROE is a function of nett income over total equity, bigger size leads to higher ROE.

On the other hand, measuring size toward MTB is explained using different school of thought. According to business cycle theory, big firm is defined as a firm whose growth has reached maturity level; while smaller firm is defined as a growing firm. Big firm whose growth already reached certain maturity level tend to be stabilized and therefore poses leaner growth curve, if not stagnant. On the other hand, smaller firm are still in the midst of its growth, therefore poses a steeper or higher growth curve. As market is trying to reach its maximum level of profit, smaller firm is perceived as higher earning potential while bigger firm is perceived as lower earning potential as consequence of its mature level of business phase. 
Firm's size is measure by:

Size $_{\text {it }}=\ln (\text { total asset })_{\text {it }}$

Evans (1987) stated that big firms undoubtedly have more access toward fundings compared to their smaller counterparts. These fundings can translate into lower cost of fund, better machinaries or higher quality of human resources which at the end boost up these big firm's performance. Regardless to the fact that big firm' absolute amount of asset is bigger compared to smaller firm, however, there is a maximum rate at which each individual firm can grow under given circumstances. Such growth are limited by various factors both internally and externally. Among others, internally, big firms tend to face bigger agency problem while externally, they are limited by saturated demand. Thus, at certain level, performance growth drops as the size reached to its optimum level.

\section{Previous Study and Hypothesis}

Nimalathasan and Pratheepkanth (2012) did study on impact of systematic risk management on profitability to ten listed banks in Colombo Stock Exchange during 2007 to 2011 and found that there is positive association between DOL, DFL to nett profit. Positive association also found on DOL and DFL to ROCE and ROE. Yoon and Jang (2005) analyzed the effect of financial leverage to profitability and risk of listed restaurant industry in US between 1998 to 2003 and found that firm size play important role on firm ROE and that bigger firm has higher profitability and significantly lower risk compared to smaller firms.

Gatsi, Gadzo and Akoto (2013) studied on how working capital management and leverage influenced firm' profitability in insurance industry in Ghana. They were using financial leverage and operating leverage as benchmark for capital structure. Other independent variable were growth, GDP and firm size. The result found that degree of financial leverage and liquidity are inversely related to profitability while operating leverage is positively related to profitability.

Akbas and Karaduman (2012) did study on the role of firm size on profitability in listed manufacturing firms in Istanbul Stock Exchange from 2005-2011. The study shows that firm size, both in terms of total asset and total sales has positive impact on profitability. Tayyaba (2013) studied the effect of leverage (DOL, DFL, DCL) on profitability of the oil and gas sector in Pakistan during 2007-2012. He found that there exist very weak, positive correlation between DFL and DOL to ROE but they are not statistically significant. Further, he found that there is no significant relationship found between DOL, DFL and DCL to ROA, ROE, ROI and EPS.

Feijoo and Jorgensen (2010), on their research "Can Operating Leverage be the Cause of the Value Premium?" trying to find the relationship between DOL, DFL and size (using market valuation as proxy) to book to market ratio and found that there is positive 
relationship between $\mathrm{DOL}$ and book to market ratio. Further, they found weak, positive association between size (using market valuation as proxy) and DFL toward book to market ratio, after controlling the market equity.

Finally, Berk(1997) did study about the impact of size and size effect on stock return using 20 years US stock data (1967-1987). He found that firm size is better be derived from market capitalization rather than either book value or sales, eventhough the finding revealed that both book value and sales have the same (weaker) effect compared to market capitalization. Berk also found that firm size has inverted value to market return. This means smaller firm tend to produce higher market return. Further, Gomez, Hodoshima and Kunimura (1998), using data between 1957 and 1993 also confirmed that Berk (1997) theory was also proven in Japanese stock market.

Based on the theory and previous studies, hypothesis in this thesis are as followed:

1. Firms with high fixed asset ratio have higher business risk compared to firms with low fixed asset ratio.

2. Highly financial leveraged firms have higher financial risk compared to lowly financial leveraged firms.

3. Business risk and financial risk contribute impact on firm performances either individually or simultaneously

4. Size brings positive impact toward ROE and adverse impact toward MTB.

\section{RESEARCH METHODS}

This study uses quantitative and data panel regression. Panel data regression can be estimated by using Pooled Least Square (PLS). Based on the problem statement and analytical model, variables described in this paper are identified as followed:

1. Dependent variables are the profiability measures. There are two kinds of profitability measures used: accounting profitability performance and market performance. Accounting performance used is return on equity (ROE) while market performance used is market to book ratio (MTB).

2. Independent variables are degree of operating leverage (DOL) and degree of financial leverage (DFL).

3. Control variable is size

Analytical model for this thesis is as followed:

1. For first and second problems we use two-independent sample t-test with the following formula:
a. $t=\frac{\overline{D O L}_{H F A}-\overline{D O L}_{L F A}}{\bar{S}_{\overline{D O L}} \overline{H F A}_{-}-\overline{D O L}_{L F A}}$
b. $\overline{D O L}_{H F A} \quad=$ Average $\mathrm{DOL}$ of high fixed asset firms 


$$
\begin{aligned}
\overline{D O L}_{L F A} & =\text { Average DOL of low fixed asset firms } \\
S_{\overline{D O L}_{H F A}-\overline{D O L}_{L F A}=} & \text { Standard deviation of difference between average } \\
& \text { DOL of high fixed asset and average DOL of low fixed asset } \\
& \text { firms. }
\end{aligned}
$$

c. $\quad t=\frac{\overline{D F L}_{H L}-\overline{D F L}_{L L}}{S_{\overline{D F L}_{H L}-\overline{D F L}_{L L}}}$

$\overline{D F L}_{H L} \quad=$ Average DFL of highly leverage firms

$\overline{D F L}_{L L} \quad=$ Average DFL of low leverage firms

$S_{\overline{D F L}_{H L}}-\overline{D F L}_{L L}=$ Standard deviation of differece between average DFL of

highly leverage and average DFL of lowly leveraged firms.

2. At the third step we use multivariate regression with the following model:

$$
\begin{array}{lll}
F P_{i t} & =\beta_{0}+\beta_{1} D O L_{i t}+\beta_{2} D F L_{i t}+\beta_{3} \text { Size }_{i t}+\varepsilon_{i t} . \\
F P_{i t} & = & \text { Firm performance } i \text { at time } t \\
\beta_{0} & = & \text { Constant } \\
\beta_{1,2,3} & = & \text { Regression coefficient } \\
D O L_{i t} & = & \text { DOL of firm } i \text { at time } t \\
D F L_{i t} & = & \text { DFL of firm } i \text { at time } t \\
S i z e_{i t} & = & \text { Size of firm } i \text { at time } t \\
\varepsilon_{i} & = & \text { Error coefficient } i
\end{array}
$$

\section{RESULT AND ANALYSIS}

DOL and DFL are measure of risk. We put both DOL and DFL as absolute value for two reasons. First, we are interested to learn the magnitute of risk rather and its direction. Secondly, having a negative risk is illogical. For those reasons, we put both at absolute value.

\section{Comparison analysis of DOL between highly and lowly fixed asset firms}

\section{Table 1}

T-test result for DOL of highly and lowly fixed asset firms

\begin{tabular}{llll}
\hline & \multicolumn{4}{l}{ Independent Sample Test for DOL } \\
\hline Fixed asset/total asset & $\mathrm{N}$ & Mean & T test for equality of means \\
High & 130 & 16.41 & 0.211 \\
Low & 130 & 9.79 & \\
\hline
\end{tabular}

As presented on table 1, the research shows that in high fixed asset/total asset group of companies have higher average DOL (that is, 16.41) compared to low fixed asset/total asset group of companies (that is, 9.79). As DOL is derived from changes of EBIT divided by changes of sales, this shows that firms with high fixed asset are tend to be more sensitive to changes of operational profit.

\section{Comparison analysis of DFL between highly and lowly financial leveraged firms.}


Table 3

T-test result for DFL of highly and lowly financial leveraged firms

\begin{tabular}{lccl}
\hline & \multicolumn{2}{l}{ Independent Sample Test for DFL } \\
\hline Total liability/total asset & $\mathrm{N}$ & Mean & T test for equality of means \\
High & 130 & 9.84 & 0.012 \\
Low & 130 & 2.14 &
\end{tabular}

Table 3 shows that in high total liability/total asset group of companies have higher average DFL (that is, 9.84) compared to low total liability/total asset group of companies (that is, 2.14). proving that firms with higher total liability have significantly higher financial risk compared to those with less liability. As DFL is derived from changes of nett profit over changes of operational profit, therefore it shows that high level of liability signals higher sensitivity over firm's operational profit level.

\section{Impact of DOL, DFL and Size toward Firm Performance}

Panel data regression can be estimated by using either one of these three methods: Pooled Least Square (PLS), Fixeded Effect Model (FEM) or Random Effect Model (REM). Chow test is performed to see whether PLS or FEM is the best statistical model to capture data behavior being tested. Provided that Chow value (commonly stated as calculated F-value) is less than F-table value, then PLS is favored, otherwise, FEM is then favored. Further, should then Chow test result shows that FEM fits better, then Haussman test is to be performed to test whether FEM or REM fits best.

Table 4

\begin{tabular}{lll}
\multicolumn{3}{c}{ Summary of the Chow test running for ROE and MTB } \\
\hline & ROE & MTB \\
\hline SSE 1 & 166.771 & 513313.2 \\
SSE 2 & 137.118 & 402328.6 \\
$\mathrm{n}$ (number of firms) & 103 & 103 \\
$\mathrm{t}$ (time period) & 5 & 5 \\
$\mathrm{k}$ (number of independent variables) & 3 & 3 \\
Chow value & 0.8692 & 1.10 \\
$\quad \mathrm{~F}\{5 \% ; 102,409\}$ & 1.3 & 1.3 \\
\hline
\end{tabular}

Table 5

Regression test on ROE

\begin{tabular}{ccc}
\hline & & ROE \\
\hline Variable & Coefficient & Probability value \\
\hline DOL & -0.000961 & 0.0380 \\
DFL & $-566 \mathrm{E}-05$ & 0.9321 \\
Size & 0.026649 & 0.0938 \\
\hline \multicolumn{3}{c}{ Durbin-Watson Stat } \\
\hline
\end{tabular}


Table 6

\begin{tabular}{ccc}
\multicolumn{4}{c}{ Regression on MTB } \\
\hline Variable & MTB \\
\hline DOL & Coefficient & Probability value \\
DFL & -0.009979 & 0.6970 \\
Size & -0.010888 & 0.7678 \\
& -3.103932 & 0.0005 \\
\hline & R-squared & 0.0240 \\
\hline & Durbin-Watson Stat & 1.2828 \\
\hline
\end{tabular}

\section{Comparison of DOL between highly and lowly fixed asset firms}

At our hypothesis set forth earlier, we believe that firms with high fixed asset ratio have higher business risk compared to firms with lower fixed asset ratio, and this research has proven so. At the same time however, this research also found that our samples posses very high standard deviation and thus finally resulting that at $5 \%$ confidence level, their difference are statistically insignificant. This means, some of high fixed asset firms might be showing medium to high level of DOL, while some of low fixed asset firms might be showing low to medium level of DOL.

DOL measures the sensitivity of operational profit due to sales fluctuations, therefore high DOL firms signals higher risk compared to those of lower DOL firms as their operational profit is very sensitive of sales upheaval. Few possibilities of these phenomena include the existance of financial leasing service and operation subcontract.

Lessee therefore is not obligated to lease during the length of amortization period and pay higher than just calculted amortization and interest premium. On the other hand, lessee is benefited to the reduced risk and better accounting ratio. By not putting a certain equipment as an asset while at the same time able to earn operational profit from it may simply means treating an asset as variable cost instead of fixed cost in the balance sheet. This accounting treatment allows firms with low fixed asset to have high DOL. Damodaran (2009) on Leases, debt and Value stated that firms, including manufacturings often use long lived, expensive assets for their operations have options either to buy, borrow at significant portion of cost or lease. Should the firm choose leasing, logically, as these assets are used in operational activities to generate revenue and subsequently operating profit, it should be categorized as financing cost. Unfortunately, both US and international accounting standards choose to ignore this logic and allow significant portion of lease expense to be treated as operating expenses. This bring consequence of misstated financial report and skewed estimate of firm profitability, leverage and value.

Partial operation agreement means purchasing half-made product elsewhere thus leaving the firm with more efficient both in terms of working process and time. As 
consequence, firms have to pay more premium price, which should already be calculated beforehand. Often, they purchase from their own group of firms. These types of firms can survive with low fixed asset while still maintaining good level of profit. This is regarded as one popular global strategy approach to win market competition.

Another side of the story is firms with high fixed asset yet low DOL, which occurs when goods produced are categorized as inelastic products. Inelastic products refers to goods whose sales do not drop as price change.

Firms with high fixed asset poses a high operational risk; this is due to the fact that during economic downturn when causing sales to drop EBIT will fall steeper compared to firms with lower fixed asset. However, at firms who produce inelastic products, sales amount does not drop as much regardless of market downturn, which is the very reason for their low DOL. Other possible reason would be that the research was done during economic stability therefore experiencing low changes of sales or EBIT.

\section{Comparison of DFL between highly and lowly financial liability firms}

In earlier chapter, we hypothesized that highly financial leveraged firms have higher financial risk compared to lowly financial leveraged firms and this hypothesis is proven in our research samples. Firms with high liability over total asset mean they carry high level of debt in their balance sheet, or aggresively finance their growth with debt. DFL measures changes of EAT over changes of EBIT. As debt creates interest obligation, highly financial leveraged firms face higher earning volatility compared to those of lower financial leveraged firms.

\section{Impact of DOL and DFL toward ROE}

DOL significantly impact ROE in negative manner while both DFL and size do not significantly impacting ROE. This means the higher business risk that being proxied by DOL, the lower is the ROE. This is not in line with what research previously done by Nimalathasan and Pratheepkanth (2012) who stated that DOL impacting ROE in positive direction. High DOL showing high sensitivity of EBIT toward sales. As stated in earlier chapter on theoretical background, ROE bring various impact toward both DOL and DFL. During good economic condition, firms with high DOL, experience higher sales and resulting higher fixeded cost compared to its variable cost and therefore resulting positive ROE. However, on the other hand, during economic recession, firms with high DOL experiences lower sales and therefore steeper fall of EBIT and subsequently falls on its ROE. Therefore, during bad economic condition firms with high DOL will pose low or even negative ROE. Firms with low DOL, however, under bad economic condition their EBIT will not be effected as much.

Based on World Bank Data, Indonesian Gross Domestic Product (GDP) growth starting at modest rate of $4.6 \%$, in 2009 , then increase by $6.2 \%$ in 2010 , slight increase 
to $6.5 \%$ in 2011 , drops back to $6.3 \%$ in 2012 and drops even further to $5.8 \%$ in 2013 . GDP measures total expenditures for all final goods and services produces in a country during certain period of time. Dropping on GDP growth except in 2010 signal unfavorable economic condition due to lower market purchasing power.

Investor should consider firms' level of risk before making investment decision. DOL is one important proxy of risk. Should investor believe that future economic condition is getting better, firms with high DOL will bring higher return; however, should economic condition is getting worse then investor should avoid investing in firms with high DOL. DFL also impacting ROE yet in insignificant level. This means DFL can not properly explain on the changes of ROE. This finding is in line with research previously done by Gatsi et al. (2013) who stated that financial leverage impacting profitability in negative manner, but does not agree with Nimalathasan and Pratheepkanth (2012) who stated that DFL brings positive impact to ROE.

High DFL shows high sensitivity of EAT toward changes of EBIT. High DFL also signals higher proportion of debt in firm capital structure that creates higher firm's payment obligation toward creditor due to interest payment. However, this research shows that financial risk being proxied by DFL is not impacting ROE. This means firms capital structure does not impacting investor return.

\section{Impact of DOL and DFL toward MTB}

Market to Book Ratio (MTB) is one of the widely used firm's market performance measure in finance. MTB is derived from market value (stock price times number of common stocks) divided by book value. Thus, high MTB signals market overpricing while low MTB signals market underpricing. In earlier chapter, we hypothesized that DOL and DFL bring impact toward MTB, which is not proven in this research. This research shows that neither DOL nor DFL bring any impact toward MTB.

MTB shows the comparison between shareholder' book value and market capitalization or stock price of that particular firm (Sharpe, 1997). This ratio captures whether a particular firm is undervalued or overvalued. A firm is said to be undervalued when its market capitalization is lower than its book value, and overvalued when its market capitalization is higher than its book value. High DOL shows that high sensitivity of EBIT toward changes of sales. During economic recession, firms with high DOL will experience lower sales and followed by even lower EBIT. This impacts firm's book value. Book value also influenced by retained earning. When retained earning grow, so is the book value, and when retained earning falls, book value will fall as well, if not negative.

Kallapur and Trombley (1999) stated that MTB signals the firm's stock price prospect. High MTB signals high market' expectation toward firm's potential, while low MTB signals low market's expectation toward firm's future. Another school of thought about negative relationship between DOL and DFL toward MTB is offered by Cooper 
(2006). Cooper developed dynamic model in which the ratio is informative of the deviation of firm's market value from its actual book value. Given that capital investment is irreversible, financially distressed firm pose very low market value while its book value remains constant. Therefore low MTB signals the extra installed capacity allows firm to expand production easily without new investment, therefore providing a high payoff to potential market value. This negative relationship between risk and market value based on Cooper (2006) model is in line with Feijoo and Jorgensen (2004).

DOL and DFL impacting MTB in negative direction insignificantly. This means both DOL and DFL do not explain factors that changes MTB. Kartikasari (2007) stated that both DOL and DFL do not bring significant impact to firm' sistematic risk. Further, she also stated that investors tend not to use fundamental analysis in making investment decision in the stock market. The fact that there is no significant impact between stock market and DOL indicates that market does not respond any changes of book values that happend due to changes of retained earning.

This research shows that investors in Bursa Efek Indonesia tend to do short term investment by using technical analysis instead of fundamental analysis. In that case, then stock price actively traded in Bursa efek indonesia might not necessarily reflects firm's fundamental condition. This is proven from this research, that neither business risk nor financial risk bring any impact to firm's market performance.

\section{Impact of size toward firm performances}

We hypothesized that size posses negative impact toward firm performances. The research result shows that size does not significantly impact ROE, but significantly impacts Market to Book value in negative manner. Size impacting ROE in positive direction, yet it is statistically insignificant. This finding is not in line with Yoong and Jang (2005) and Akbas and Karadunan (2012) who stated that size impact ROE positively as bigger firms have higher profitability and wider access toward low cost funding therefore pose lower risk compared to smaller firms and therefore resulting in higher ROE.

This research shows that firm accounting performance measured by ROE does not impacted by firm size. Bigger firms do not necessarily poses higher ROE while smaller firms do not necessarily pose lower ROE. This is true as firms who have reached maturity level tend not to be able to increase its profitability in significant manner.

In this research, size is measured by In of total asset. Possible explanation of insignificance impact between size to ROE is the suboptimal use of asset to create profit. Thus, further study is needed to find whether firm asset has been productively used to create profit. 
Size impacting MTB in negative direction significantly. This proves our earlier hypothesis that there is negative relationship between size and MTB. High MTB means high market expecatation toward firm's future potential. This research shows that the bigger is the firm size the smaller is the MTB. This means market perceived bigger firm will bring smaller return compared to return brought by smaller firms. Further, this also means that bigger firms have smaller growth potential therefore subseqently bring smaller return. On the other hand, these firms, due to its reputation and access to funding have stronger resistant toward crisis, and therefore have smaller risk. Using the same logic, smaller firm has higher risk especially during crisis, however they have bigger room for improvement and flexibility toward new opportunities, therefore market perceived it with higher return potential.

\section{CONCLUSION}

Based on the research we did, we hereby conclude as followed, eventhough there exist difference between average DOL of high fixed asset firms and average DOL of low fixed asset firms as expected, however the difference is not statistically significant. There exist significant difference between average DFL of highly leveraged firms and average DFL of lowly leveraged firms. Thus, highly leveraged firms have significantly higher degree of financial leverage compared to lowly leveraged firms. In terms of firms ROE, neither DOL nor DFL has impact toward it; however, size does bring positive impact toward ROE. All DOL, DFL and size are impacting MTB in negative manner, yet only size bring statistically significant impact.

\section{REFERENCES}

Akbas, H. and Karaduman, H. 2012. The Effect of Firm Size on Profitability: An Empirical Investigation on Turkish Manufacturing Companies. European Journal of Economics, Finance and Administrative Sciences, December, 2012. Berk, J. 1987. Does Size Really Matter? Financial Analysts Journal, September/October 1997, Vol. 53, no 5:6-8.

Blease, Kaen, Etebari, Baumann. 2010. Employees, firm size and profitability in US manufacturing industries.

Chou, C.and Su,R. 2007. On the Relation of Systematic risk and Accounting Variables, Journal of Mangerial Finance Vol. 33 no 8

Damodaran, A. 2009. Leases, Debt and Value. Stern School of Business, New York

DeAngelo, H. And Masulis, R. 1980. Optimal capital structure under corporate and personal taxation. Joural of Financial Economics 8:3-29

Donaldson, G. 1961. Corporate debt capacity. Division of Research, Harvard Graduate School of Business Administration, Harvard University 
Evans, D. 1987. The Relationship Between Firm Growth, Size and Age: Estimates for 100 Manufacturing Industries. The Journal of Industrial Economics vol. XXXV, June 1987 no. 4

Feijoo, L.,Jorgensen, R. 2004. Can Operating Leverage be The Cause of the Value

Premium? Journal of Financial Management, Vol. 39, issue 3, p. 1127-1154

Gatsi, J., Gadzo, S., Akoto, R. 2013. Degree of Financial and Operating Leverage and

Profitability of Insurance Firms in Ghana. International Business and Management:

Vol. 7, No. 2, 2013, pp. 57-65

Kiymaz, H.and Hodgin, R. 2003. Enchancing Clarity and Completeness of Basic Financial Tect Treatments on Operating Leverage. Journal of Economic and Finance Education Vol. 2 no 2

Kroll,Y.and Aharon,D. 2014. Analytical Redefinition of Degree of Operating Leverage and Managerial Investment Decisions. Journal of Managerial Finance

Vol 40 no 7

Long, M.and Malitz, I. 1985. Investment Patterns and Financial Leverage. National

Bureau of Economic Research p. 325-352

Pervan, M., Visic, J. 2012. Influence of Firm Size on Its Business Success. Croatian Operational Research Review (CRORR): Vol. 3, 2012.

Sudana, I Made.,2011. Manajemen Keuangan Perusahaan teori \& Praktik. Penerbit Erlangga; Jakarta

Santarelli, E., Klomp, L., Thurik, A.R. 2004. Gibrat's Law: an Overview of the Emprical Literature. International Studies in Entrepreneurship Vol. 12, 2006,

pp 41-73

Tayyaba, K. 2013. "Leverage"-An Analysis and Its Impact on Profitability with Reference to Selected Oil and Gas Companies. International Journal of Business and Management Invention. www.ijbmi. org Vol. 2, Issue 7, pp. 50-59

Yoon, E. and Jang, S. 2005. The Effect of Financial Leverage on Profitability and Risk of Restaurant Firms. Journal of Hospitality Financial Management: Vol. 13: Iss. 1, Article 24 